\title{
A Utilitarian Argument Against Torture Interrogation of Terrorists
}

\author{
Jean Maria Arrigo \\ Project on Ethics and Art in Testimony, Irvine, California, USA
}

Keywords: torture, interrogation, terrorism, utilitarianism, military ethics, human rights

\begin{abstract}
Following the September 2001 terrorist attacks on the United States, much support for torture interrogation of terrorists has emerged in the public forum, largely based on the "ticking bomb" scenario. Although deontological and virtue ethics provide incisive arguments against torture, they do not speak directly to scientists and government officials responsible for national security in a utilitarian framework. Drawing from criminology, organizational theory, social psychology, the historical record, and my interviews with military professionals, I assess the potential of an official U.S. program of torture interrogation from a practical perspective. The central element of program design is a sound causal model relating input to output. I explore three principal models of how torture interrogation leads to truth: the animal instinct model, the cognitive failure model, and the data processing model. These models show why torture interrogation fails overall as a counterterrorist tactic. They also expose the processes that lead from a precision torture interrogation program to breakdowns in key institutions - health care, biomedical research, police, judiciary, and military. The breakdowns evolve from institutional dynamics that are independent of the original moral rationale. The counterargument, of course, is that in a society destroyed by terrorism there will be nothing to repair. That is why the actual causal mechanism of torture interrogation in curtailing terrorism must be elucidated by utilitarians rather than presumed.
\end{abstract}

Address for correspondence: Jean Maria Arrigo, Ph.D., Virginia Foundation for the Humanities, Affiliate, and Project on Ethics and Art in Testimony, 110 Oxford Street, Irvine, California 92612, USA; Email: jmarrigo@pacbell.net.

Paper received, 25 March 2003: revised, 17 February 2004: accepted, 18 February 2004. 1353-3452 @ 2004 Opragen Publications, POB 54, Guildford GU1 2YF, UK. http://www.opragen.co.uk 


\section{INTRODUCTION}

Following the September 2001 terrorist attacks on the United States, much support for torture interrogation of terrorists has emerged in the public forum, largely based on the "ticking bomb" scenario. National polls have reported $45 \%{ }^{1}$ and $32 \%{ }^{2}$ approval; a large web-site vote indicated $73 \%$ approval. ${ }^{3}$ The appeal was that rare use of torture interrogation of key terrorists could thwart terrorist plans of mass destruction at minimal cost to civil liberties and democratic process. Moreover, a strictly monitored legal program would eliminate current, illegal covert programs. ${ }^{4}$ The May 2004 revelation of U.S. Army sexual tortures of Iraqi detainees at the Abu Ghraib prison West of $\mathrm{Baghdad}^{5}$ may dampen public enthusiasm for a domestic program of torture interrogation. Yet the issue remains for another day. As stated by Derk Roeloffsma, editor of the newsletter of the Association of Former [U.S.] Intelligence Officers: ${ }^{6}$

[T]here is a tragic conflict between the principles by which we wish to live together, "with liberty and justice for all," and the duty and conscience of those who bear responsibility for protecting the lives of others. Extracting information from the enemy is vital to the fulfillment of that responsibility and torture and degradation can deliver it

I aim to demonstrate the contrary, that torture and degradation do not deliver as advertised, that torture interrogation fails overall as a counterterrorist tactic to create public security. In addition, the establishment of an official torture interrogation program produces long-term dysfunctions in key institutions - notably health care, biomedical research, the police, the judiciary, and the military-due to institutional dynamics that are independent of the original moral rationale for torture. Deontological and virtue ethics provide incisive arguments against torture interrogation. But these arguments do not drive public consensus on which duties or virtues should be upheld by government officials and scientists at the cost of devastation by terrorists. As a social psychologist I wish to speak directly to those whose institutional positions render them accountable for national security in a utilitarian framework. ${ }^{\mathrm{a}}$ Therefore, I consider the practical aspects of a potential domestic program of torture interrogation.

\section{PLANNING A PROGRAM OF TORTURE INTERROGATION}

Ethicist John Rawls proposed that any utilitarian moral argument for a program of action should include assessment of the practices required to implement that program. For with careful attention to implementation, there is less danger of adopting means that do not actually reach the desired ends. ${ }^{7}$ This is the course I pursue. I pass over

a. No one is proposing torture of all terrorist suspects in all urgent situations, so act utilitarianism rather than rule utilitarianism is at stake here. 
foundational issues, such as the definition of "torture"b and the morality of torture per se. I do not reach as far as state-level issues, such as international covenants banning torture. Rather, I draw from criminology, organizational theory, social psychology, the historical record, and my own interviews with intelligence professionals to explore the design, implementation, and consequences of an official program of torture interrogation. $^{\mathrm{c}}$

There is no obvious starting point though. Some planners would start with legislation, some with choice of institutional sponsorship (e.g., police or military), and some with program procedures (e.g., recruitment and training). Such starting points presume the efficacy of torture interrogation. The French officer Roger Trinquier who planned the counterinsurgency campaign in Algeria had full confidence in the efficacy: "If the prisoner gives the information requested, the examination is quickly terminated; if not, specialists must force his secret from him.... Science can easily place at the army's disposition the means for obtaining what is sought." "But can science indeed achieve this success?

Causal models of human behaviour are much debated by philosophers of science. ${ }^{9}$ Causal relationships in the statement, "The soldiers fired as the van approached a checkpoint because they believed the driver was a suicide bomber," are essentially different from causal relationships in the statement, "The driver died because a bullet entered his brain." A torture interrogation program depends on a complex interaction of causal relationships of both types, in which both human motivation and human physiology figure crucially but uncertainly.

According to policy studies, the quintessential element of program design and implementation is a sound causal model relating inputs to outputs. ${ }^{10}$ Can we put (only) key terrorists into the torture chamber and put out at the other end timely and true knowledge of terrorist plans? Can just a little bit of torture interrogation cause just a little bit of harm to a democratic society? For orderliness of exposition, I examine three, increasingly realistic models of how torture interrogation leads to truth: (1) the animal instinct model, (2) the cognitive failure model, and (3) the data processing model. The inadequacies of each model lead on to the next, with increasing involvement and compromise of key social institutions - that is to say, with unintended inputs and unintended outputs of increasing consequence. To these causal models, I append (4) the rogue models of outsourcing torture interrogation to foreign or illegal information services, without regard for causal explanation.

In outline:

b In international law and the human rights literature, torture is commonly understood as "the infliction of severe pain (whether physical or psychological) by a perpetrator who acts purposefully and on behalf of the state."-Amris, S., \& Arenas, J. (2003) IRCT impact assessment study (I-V). The work field of torture. Torture (Suppl. No. 1) 13: 7-30. p. 11.

c. Amnesty International reported state-sponsored torture or severe abuse in over 100 countries in 2002. [Amnesty International. (2003) Amnesty International Report 2003. Author, London.] This paper, which draws on published studies and author interviews, by no means represents all countries that use torture. 
Table 1: Models of How Torture Leads to Truth for A Program of Torture Interrogation of Terrorist Suspects

\author{
Description of How \\ Torture Leads to Truth
}

\author{
Special Institutional Requirements \\ of Model
} Major Difficulties
for Model

\section{The animal instinct model of truth telling - a causal model}

In order to escape pain or death, the subject complies with the demands of the torturer.-The prototype is torture of the terrorist who set the ticking bomb.
- Assistance of medical practitioners before, during, and after torture sessions.
- Bodily injury impairs subject's mental ability to convey the truth. $\bullet$ Subject dies prematurely. $\bullet$ Torturer cannot control subject's interpretation of pain.

\section{The cognitive failure model of truth telling - a causal model}

The physiological and psychological stress of torture renders the subjects mentally incompetent to muster deception and to maintain their own interpretations of pain.

-The prototype is torture of fanatics, martyrs, and heroes.
- Biomedical and psychological research into techniques, detection, and concealment of torture. - Establishment of a torture interrogation unit, with training of torturers in sophisticated methods.
- Lengthy interrogation diminishes the value of the information obtained.

- Torturers are ruined through training and deployment.

- Subjects' true statements cannot be distinguished from the erroneous or deceitful.

\section{The data processing model of knowledge acquisition - a causal model}

Torture provokes ordinary subjects to yield data (both true and false) on an opportunistic basis, for comprehensive analysis across subjects. - The prototype is dragnet interrogation of terrorist suspects and other deviants.
- Coordination of torture agencies with the police.

- Coordination of torture agencies with the judiciary. $\bullet$ Accommodation of torture units within the military and the government.
- Analysts are overwhelmed by data. - Torture motivates more terrorists than it incapacitates $\bullet$ Torturers and their institutions are corrupted.

- Moral outrage alienates torturers' constituency.

\section{Rogue torture interrogation services - a non-causal model}

Torture is emotionally or culturally inseparable from other methods of acquiring terrorist information, or it is one method among many in a hitor-miss approach.-The prototypes are brutal foreign intelligence agencies, covert U.S. torture interrogation sites, and "information services" of organized crime.
- Discreet government and military liaison with rogue torture interrogation services.
- Biases and ulterior motives of torturers invalidate the interrogation. - Torture services empower competing political or criminal entities.

- Torturers acquire information for blackmail of authorities and for criminal operations.

\section{THE ANIMAL INSTINCT MODEL OF TRUTH TELLING}

The January 2002 cover of The Atlantic Monthly asked in large print, "MUST WE TORTURE?" Terrorism analyst Bruce Hoffman from Rand Corporation suggested we 
must. He reported sympathetically on his meeting with a Sri Lankan intelligence officer- "Thomas" - whose terrorist opposition "eclipse[d] even bin Laden's al Qaeda in professionalism, capability, and determination." In one vignette, ${ }^{11}$

Thomas's unit had apprehended three terrorists who, it suspected, had recently planted somewhere in the city a bomb that was then ticking away.... The terrorists - highly dedicated and steeled to resist interrogation - remained silent.... So Thomas took his pistol from his gun belt, pointed it at the forehead of one of them, and shot him dead. The other two, he said, talked immediately; the bomb, which had been placed in a crowded railway station and set to explode during the evening rush hour, was found and defused, and countless lives were saved.

In this compelling ticking-bomb scenario, terrorists give up their secrets in a timely manner to escape immediate pain or death, a causal pattern I label the animal instinct model. The potent causal element here is the torturer's creation of a situation in which the animal nature of the subject overrides the human will or reason of the subject so as to preserve his life or relieve unbearable pain. Ancient Greek courts placed great faith in testimony obtained through torture of slaves. As Aristotle explained, free men can reason about the personal consequences of truth and false testimony, and they will testify, even under torture, to their long-term advantage; but slaves, deprived of reason, are compelled by their feelings to meet the torturer's demands so as to terminate the pain. $^{12}$

The first flaw in the animal instinct model is the frailty of the mind under bodily assault. As explained by neurologist Lawrence Hinkle, who examined Korean War veterans after communist "brain-washing": ${ }^{13}$

The human brain, the repository of the information that the interrogator seeks, functions optimally within the same narrow range of physical and chemical conditions that limit the functions of human organs in general.... Any circumstance that impairs the function of the brain potentially affects the ability to give information as well as the ability to withhold it.

In particular, the interrogation fails if the terrorist loses consciousness before revealing his plans. Under the Shah of Iran in the 1970s, political radicals at risk of torture were therefore advised to fast so as to lose consciousness at the outset of torture. ${ }^{14}$ The animal instinct model clearly requires medical assistance at the torture site.

Assistance of Health Professionals in Torture Interrogation. Routine participation of medical personnel in state-sponsored torture interrogation has been documented worldwide. Medical professionals determine the types of torture a person can endure, monitor the person for endurance under torture, resuscitate the person, treat the person to prepare for further torture, and administer non-therapeutic drugs. To cover up torture, physicians falsify health certificates, autopsy reports, and death certificates. ${ }^{15}$ Studies of survivors variously show medical participation in the range of $20 \%$ to $40 \%$ of torture cases, or even the majority. ${ }^{16}$ Coercive interrogation manuals, such as the 
1983 edition of the U.S. Army's School of the Americas manual, call for the services of physicians and psychiatrists. ${ }^{17}$

To obtain the physicians' perspective, the Indian Medical Association surveyed a random sample of 4,000 members. ${ }^{18}$ Of the fifth who responded, $58 \%$ believed torture interrogation permissible; $71 \%$ had come across a case of probable torture; $18 \%$ knew of health professionals who had participated in torture; $16 \%$ had witnessed torture themselves; and $10 \%$ agreed that false medical and autopsy reports were sometimes justified.

Government-sponsored torture generates deep conflicts within medical communities and between governments and their medical communities. In Turkey physicians have falsified evidence of torture in post-detention medical examinations, to the dismay of their patient-oriented colleagues. ${ }^{19}$ Prompted by the longstanding torture of Kurdish separatists, Turkish physicians have established five torture treatment centers. Government authorities demanded patient lists and brought physicians to trial for criticizing the government. Turkish physicians have been harassed, arrested, and even tortured, as regularly reported in international medical journals. ${ }^{20}$

Proponents of a U.S. torture interrogation program must consider how to deal with both zealous cooperation and vigorous resistance from American health professionals, particularly those with access to sensitive information. The challenges will be intense in some specialties, such as military medicine ${ }^{21}$ and forensic medicine. ${ }^{22}$ In 2001, a group of Mexican forensic doctors confronted state-sponsored torture with a pledge to document torture "without distinction or discrimination of any kind, even under threat. ${ }^{, 23}$ A recent opinion piece in the Western Journal of Medicine, by medical members of past U.S. delegations to the Organization for Security and Cooperation in Europe, observed: "How sadly ironic it would be, now, for the United States to join the ranks of the countries it has long condemned for [torture]. ${ }^{24}$ The World Medical Association has officially prohibited physicians' participation in torture. ${ }^{25}$ Domestic professional associations are thus often linked to the ethics codes of international associations.

The larger lesson here is that a national security rationale for torture does not suspend, without tumult and schisms, the ethics codes of professions whose participation is required. Judging from the experience of other countries, similar turmoil might be anticipated in clinical psychology, journalism, and law. ${ }^{26}$

Torturers' Failure to Control Subjects' Interpretation of Pain. A second flaw in the animal instinct model is the mental resistance of fanatics, martyrs, and heroes to coercion. A former U.S. Air Force intelligence liaison officer to counterterrorist police teams in the Middle East (hereafter referred to as the Air Force interrogator) gave this example of an interrogation by the Turkish National Police (TNP): ${ }^{\mathrm{d}}$

d. This and later quotations were drawn, with permission, from my correspondence with a retired Air Force interrogator prior to the U.S. invasion of Iraq in 2003. Due to the current political situation, I am obliged to anonymize his contributions. The entire correspondence and numerous supporting Air Force documents were reviewed for apparent authenticity on April 28, 2003, by 
In 1979 the $[\mathrm{TNP}]$ team captured She had personally killed 32 Turkish National Police officers.... Trying to obtain intelligence out of one of the most violent people on earth is a bit of trouble.... She screamed, spat, kicked, ripped up her holding facility, refused to talk.... She tried to cut her wrists with a plastic knife; she ran full force with her head onto the wall. She threw feces at all of us. Then the word came down to go to Level 1 [i.e., potentially fatal torture]. .... She stayed silent.... [During transport] she tried to jump from the speeding vehicle...after laughing she loved shooting police and Americans.

For a long historical comparison, examination of court records for 625 cases of juridical torture in France, from the 1500s through the mid-1700s, showed that, depending on the province, in $67 \%$ to $95 \%$ of cases the accused did not confess-on the rack, under repeated drowning, crushing of joints, and the like. ${ }^{27}$ Of course, it is unknown who among the accused were actually guilty, as will be the case with many terrorist suspects.

Modern psychology maps the intractability of the psyche. In general, people tend to react against those who constrain their freedom of action (reactance theory). ${ }^{28}$ People tend to become more dogmatic and tenacious in their belief systems when reminded of their mortality (terror management theory). ${ }^{29}$ And under extreme stress, as during a car crash, rape, or battlefield injury, people may dissociate, that is, experience the episode as if from a distance, temporarily protected from pain and awareness of consequences (traumatic stress theory). ${ }^{30}$ For such reasons, the Air Force interrogator said he tried to interview terrorist suspects "before any heavy handed ex-Turkish farmer slapped them around."31

Even under the Nazis, torture interrogation failed to break dozens of high state officials and military commanders involved in late-war plots to assassinate Hitler. According to Peter Hoffman's History of the German Resistance: 1933-1945: ${ }^{32}$

Six months from the start of their investigations the Gestapo still had nothing like precise knowledge of the resistance movement.......This lack of information and knowledge is all the more astounding in that Himmler's men employed every means to extract confessions.... Moreover all forms of torture were used without hesitation....

Hoffman attributed the failure of the Gestapo to the "fortitude of their victims."

Closer to home for Americans, during the months and years of North Vietnamese torture of American POWs, Commander James Stockdale estimated that under 5\% of his 400 fellow American airmen succumbed to North Vietnamese demands for antiAmerican propaganda statements. ${ }^{33}$ These examples expose the bigotry in the

political scientist C.B. Scott Jones, Ph.D., a retired U.S. Navy officer with 15 years experience in naval intelligence and subsequently a senior U.S. Senate staffer.

Regarding the example that follows, the interrogator said, "My team had nothing to do with the ... fiasco except to try to persuade the TNP not to harm her as she was present at the assassination of four Americans." 
expectation that key enemy terrorists will readily give up their plans and associates under torture.

The animal instinct model ultimately fails because the physiological experience of pain is mediated by individual and cultural interpretation. Anthropologists identify the "punitive pain" envisioned by the torturer as only one of several competing interpretations. In addition to the valor of "military pain;" exemplified by the female Turkish terrorist above, German resistors, and Stockdale, we recognize the "medical pain" of surgery, the "athletic pain" of the marathon; and the "sacrificial pain" of martyrs. ${ }^{34}$ A psychological study of 79 Palestinians detained by the Israelis identified seven personal meanings of their prison torture, such as "struggle between strength and weakness" of character; "heroic fulfillment" of their role as liberators of their people; a "developmental task;" and "return to religion." "Among political radicals in Iran in the late 1960s and 1970s, endurance of torture, not direct service to the revolutionary cause, determined who would rise as a political leader. ${ }^{36}$ Speaking of the after-effects of torture, Jose Quiroga, the medical director of the Program for Torture Victims in Los Angeles, CA, remarked: “The effect of torture depends more on the victim's interpretation of the torture than on the intensity or length of the torture. ${ }^{37}$

\section{THE COGNITIVE FAILURE MODEL OF TRUTH TELLING}

In the cognitive failure model of truth telling, torture renders the subject cognitively incapable of maintaining his or her own interpretation of pain. The potent causal element here is the torturer's disorientation and diminution of the subject's will. As understood in contemporary criminal psychology, overwhelming physical and mental stress create a state of disorientation in which the subject is unable to maintain a position of self-interest and becomes suggestible or compliant under interrogation. ${ }^{38}$ Similarly, in the 15 th to 18 th Centuries, European courts employed juridical torture in the belief that bodily suffering eliminates self-will, which accorded with Catholic asceticism. In the absence of self-will, the accused was presumed to expose the truth in involuntary testimony or nonverbal signs. ${ }^{39}$

In contrast to the resistance of Stockwell's airmen to North Vietnamese physical tortures, only 5\% of the repatriated American POWs held by the Chinese in the Korean War decisively resisted the cognitive disorientation - and reorientation - tactics of the Chinese; $15 \%$ collaborated to the extent they were court-martialed or dishonorably discharged. The "brain-washing" regimen of the Chinese included solitary confinement, lack of stimulus, unremitting observation by guards, sleep deprivation, ridicule, pressure to confess to unstated crimes, and interminable instruction in Marxism and Maoism, as well as deprivations and threats. "Physical abuse and mistreatment were frequently the results of resistance, but seldom the prelude to participation" (i.e., collaboration), with only 3\% of the "Participators" severely mistreated. $^{40}$

(Here I pass over a considerable lore pointing to the greater efficacy of noncoercive interrogation based on social skills: subtlety and finesse of interrogation, ${ }^{41}$ sympathy with the subject, ${ }^{42}$ appeal to the subject's self interest, ${ }^{43}$ outright deceit and trickery, ${ }^{44}$ and religious counselling by a trusted cleric.) 45 
The cognitive failure model demands cutting edge biomedical research into techniques of torture that bring swift results. Only by constant innovation can torturers stay ahead of savvy terrorist organizations and human rights monitors. Research-based torture technology requires a corps of trained torturers. I explore these two institutional requirements next.

Biomedical Research for Torture Interrogation. Twentieth Century researchers developed numerous techniques to induce disorientation, such as psychiatricpharmacological substances, electroshock, and electromagnetic resonance. ${ }^{46}$ But how could torture-interrogation research proceed in the United States, and what sort of scientists might participate?

Consider a Cold War strategy for a program of similarly stigmatized research, the mind control Project MKULTRA of the Central Intelligence Agency (CIA). A 1977 Senate investigation disclosed that the CIA had simply contracted with researchers at over 80 universities, hospitals, chemical and pharmaceutical companies, and research institutes through a front funding agency. The Human Ecology Society, as it was called, was co-founded by the neurologist Lawrence Hinkle who had examined the POWs "brainwashed" in Korea. Hinkle had a major planning role in MKULTRA. ${ }^{47}$ One MKULTRA subproject sought "[s]ubstances which will enhance the ability of individuals to withstand privation, torture and coercion during interrogation...." Another called for three research teams to compare various combinations of "straight interrogation, hypnosis, and drugs on subjects who had denied allegations known to be true." Admiral Stansfield Turner, then Director of Central Intelligence, stated: "I believe we all owe a moral obligation to these researchers and institutions to protect them from any unjustified embarrassment or damage to their reputations which revelations of their identities might bring. ${ }^{48}$ The U.S. Supreme Court ruled that the identities should not be revealed for security reasons. ${ }^{49}$ The overall CIA research strategy therefore remained viable.

The "war on terrorism" has produced a related research strategy. The U.S. Defense Advanced Research Projects Agency (DARPA) hosted an invitation-only conference on March 11-13, 2002, called "Scientists Helping America." According to a widely broadcast DARPA call for submissions, "The primary focus of the conference is to tap into new ideas of scientists and inventors... ." "Luminaries" from industry and academia are invited to "come and interact with real special operation forces including US Navy SEALS and US Army Green Berets.",50

What sort of scientists might respond if summoned? In a 1995 interview, I remarked to (now deceased) biological psychologist John Liebeskind on the potential contributions of his pain management research to torture interrogation. In most fields of animal experimentation, anaesthetics and analgesics are administered to mask the experience of injury; however, pain management researchers intentionally induce pain in laboratory animals to study the mechanisms of pain. Liebeskind, a Fellow of the National Academy of Sciences and a great humanist, replied with candor and insight: ${ }^{51}$

I don't think I am or would be in a good or well informed position to assess the ethical consequences of any military project I might be asked to help with. They wouldn't tell me the truth (and I certainly wouldn't know if they had or not), and I 
wouldn't really understand all the ramifications even if they did or thought they did. So if we are developing something military and are in competition with other countries, I would feel an "us versus them" dilemma, and there surely aren't very many "thems" I would trust more than us.

Biomedical applications to torture interrogation may even have a humanitarian theme. A neuroscientist recently developed a "brain fingerprinting" technique. Words or pictures relevant to an event are flashed onto a computer screen. Measurement of the subject's brain-wave responses supposedly determine whether the subject has knowledge of corresponding events. ${ }^{52}$ The previously mentioned Air Force interrogator suggested that we "use the brain fingerprint to find out who the terrorists are, then we torture them...," thus avoiding torture of innocents. But he warned that "like the polygraph, the machine would have a wide range of [desirable and undesirable] effects." $" 53$

Israeli response to Palestinian resistance illustrates the motive for torture research to stay ahead of savvy enemies. ${ }^{54}$ A former Palestinian prisoner proudly explained: "We learned about all the types of ill-treatment and the techniques that the secret police use, and we learned to observe the behaviour of enemy officers during our interrogation"- thereby strengthening cognitive orientation under torture. Turkish counterinsurgency policy illustrates the motive for research into concealment and detection of torture to stay ahead of human rights monitors. The European Union Commission postponed Turkey's admission into the European Union because of the flow of torture victims from Turkey. To gain the political and economic advantages of membership, Turkey attempted to develop torture techniques that leave no medical trace. European forensic experts, meanwhile, employed successively more refined methods of detection, such as bone scintigraphy, ultrasonography, CAT scans, and MRI's. ${ }^{55}$ Thus develops the race between techniques of torture and techniques of resistance and detection.

Torture then spreads to foreign governments through exchange of torture technology. Argentina gave classes in torture to Latin American military officers, and Brazilian torturers trained Chileans. ${ }^{56}$ The U.S. School of the Americas, with its coercive interrogation manuals, was widely known as a training school for Latin American dictators during the Cold War. Amnesty International cites the United States as the largest international supplier of electroshock weapons-stun guns, electro-shock batons, and the like - to governments that practice electro-shock torture. ${ }^{57}$

Another unintended consequence of biomedical research on torture is the opportunity for secret, illegal research on human subjects for other purposes. Administrators of torture interrogation programs cannot prevent alternative research on human subjects by their own biomedical scientists, ${ }^{58}$ who have negotiating power over these very valuable resources. ${ }^{59}$ Historically, government-sponsored ethics investigations of the CIA's mind control Project MKULTRA ${ }^{60}$ and the Department of Energy's radiation experiments ${ }^{61}$ exposed extraneous, excessive, and criminal human subjects research.

Similarly, as will be seen later, torture interrogation is a resource that cannot be entirely denied to certain military, police, and government agencies for their own applications. 
Establishment of a Torture Interrogation Unit. Political scientist Harold William Rood, who for ten years taught field interrogation of prisoners of war in military intelligence schools, explained the institutionalization challenge as follows. Many agencies must coordinate in a counterterrorist operation. Reliability and accountability are therefore essential. Outlaws and madmen cannot be hired as torturers by an otherwise orderly agency. The torturers have to be well trained and professional: "To deliberately torture a person over a period of six weeks is asking a lot of human beings." ${ }^{\text {"2 }}$ The Los Angeles Times recently reported a former counter-terrorism official as saying that one of bin Laden's top deputies, captured in March 2002, "will be put through the ringer for days and weeks....It will take at least 96 hours to get him to spill everything....If not, they will keep going...." ${ }^{, 63}$ This is the work of a highly trained team of interrogators.

Military training programs have been studied through interviews with former torturers in Greece, ${ }^{64}$ Argentina, Brazil, Chile, and Uruguay, ${ }^{65}$ Nicaragua ${ }^{66}$ and Israel. ${ }^{67}$ As a composite picture from these studies, trainees are typically selected on the basis of their ability to endure hardship and pain, for correct political beliefs, trustworthiness, and obedience. Often the young, the lower class, or the poorly educated are recruited, or even kidnapped. Brutal training at the outset desensitizes trainees to their own pain, suffering, and humiliation. Confinement and initiation rites isolate them from prior relationships. Constant physical and psychological intimidation instil obedience. Trainees first learn torture through social modelling in witness and guard roles. They usually experience tension between their new roles and their previous values, and they variously resort to denial, psychological dissociation, alcohol, or drugs. Dehumanization and scapegoating of victims are employed to relieve the bad self-image experienced by many torturers. The efficacy of shame tactics in torture tends to lead to sexual tortures which in turn contribute to stigmatization and corruption of torturers. Torturers must practice to develop their skills, so subjects are drawn from other populations when dangerous terrorists are unavailable, which further alienates the torturer from society.

Criminologist Ronald Crelinsten, who studies the career paths of torturers, writes movingly of their travails in the closed world of the torture unit. "The world of conventional morality and human decency....has been largely replaced by a new morality where disobedience" - including refusal to torture friends-"means punishment, disgrace, humiliation,...or even death." ${ }^{68}$ Alistair Horne, historian of the Battle of Algiers, concluded that torture "tends to demoralise the inflictor even more than his victim, and he gave harrowing examples of psychological impairment from the psychiatric record. ${ }^{69}$ Generally torturers win not the gratitude or admiration of their military colleagues but the contempt. After the fall of the Pinochet regime in Chile, the navy and air force did not take back officers who had worked in the secret service but considered them to be "defiled". 70

The utilitarian argument for torture interrogation, therefore, must justify the additional sacrifice of the torturers - made vulnerable to "perpetration-induced traumatic stress" $"$ and severe social stigma—or develop some hitherto-unknown 
transcendent regimen for training and after-care of torturers. This sacrifice should be expanded to include support staff and families, where secrecy, stress, and stigmatization take their toll over decades. The Air Force interrogator remarked: "Although our team [of liaison officers] could become accustomed to the [Middle Eastern] interrogation process, the secretaries that received our hand-written analysis and interrogation observations were badly shocked." ${ }^{, 72}$

As an intelligence professional, Rood further cautioned that it would be difficult to set up a program for torture interrogation without unintentionally incorporating an inside agent of the terrorists. ${ }^{73}$ In World War II, both the carefully guarded Manhattan Project and the Office of Strategic Services (precursor to the CIA) incorporated many Soviet spies. ${ }^{74}$ Counterterrorist agencies, moreover, depend on informants. As in police detective units with official informant programs, there is the perennial risk that the informant will corrupt the officer and reverse roles, so that the informant becomes the handler and the officer becomes the paid informer. ${ }^{75}$ Recently, mafioso James "Whitey" Bulger, unprosecuted murderer of 11 informants of the U.S. Federal Bureau of Investigation (FBI), was found to have been running his own agents inside the FBI-including FBI Special Agent John Connolly, whose opposition to organized crime had raised him to eminence. ${ }^{76}$ Considerations of futility are thus added to the sacrifice of torture personnel in a cost-benefits analysis.

Ultimately, the cognitive failure model for fanatics, heroes, and martyrs cannot succeed because torture interrogation provides only data, not truth. Commander James Stockdale ordered his fellow American POWs in Vietnam to "resist to the point of permanent injury or loss of mental faculty, and then fall back on deceit and distortion." 33a A famous World War II incident shows the potential of such deceit. American fighter pilot Marcus McDilda, captured by the Japanese on August 8, 1945, "revealed" under rough interrogation that the U.S. would drop atomic bombs on Kyoto and Tokyo within a few days. ${ }^{77}$ The prudent standard of truth for intelligence agencies though is not the one-shot revelation, but convergent analyses of far-ranging data.

\section{THE DATA PROCESSING MODEL FOR KNOWLEDGE ACQUISITION}

The fanatics, martyrs, and heroes scenario errs, like the ticking bomb scenario, in its focus on key terrorists. They are difficult to apprehend and likely to require great exertions from torturers. Their numerous peripheral associates are much easier to apprehend and more susceptible to interrogation-whence the inevitable trend towards dragnet interrogations. Among the detainees will be many innocent or ignorant persons, but these, too, are critical for comparison of nonterrorist with terrorist data. The time scale of the ticking bomb scenario is also extremely misleading. In FBI experience, deterrence of terrorist acts is a long-term affair, with informants, electronic surveillance networks, and undercover agents. Operations must be tracked and allowed to play out almost to the last stage to comprehend their scope. ${ }^{78}$ The potent causal element in the data processing model lies beyond the torture chamber, in the convergent analysis of vast amounts of peripheral and doubtful testimony generated by dragnet torture interrogation. 
The French General Paul Aussaresses, chief intelligence officer in the Battle for Algiers from 1955 to 1957 , credited his large-scale, merciless, torture interrogation campaign with crushing the Algerian insurgency and stopping terrorist bombings. Aussaresses' name is often brought in to support the ticking-bomb argument, but his memoir records cases of terrorists dying under torture with their secrets or exasperating him to the point of murdering them himself. ${ }^{79} \mathrm{He}$ did not run a small-scale, precision, torture-interrogation program, as envisioned by advocates in the U.S. He had an informant for each city block in the native section of Algiers. Altogether, 30\% to $40 \%$ of the men were arrested and interrogated during the war, frequently by electrical shock to the sexual organs. ${ }^{80}$ Aussaresses ran a dragnet interrogation program, which swept up the peripherally involved and the uninvolved along with occasional terrorist leaders.

The operational appeal of dragnet interrogation is evident from the December 2003 capture of defeated Iraqi dictator Saddam Hussein by U.S. forces. As described by former CIA analyst Bruce Berkowitz: "The search was conducted more like a police dragnet than a traditional intelligence investigation. Because our military controls Iraq, our personnel could roam the countryside freely, cordon off areas and interrogate sources repeatedly...., 81

Dragnet torture interrogation has been common historically. Soviet historians estimate that between 1936 and 1939 the Soviet government arrested 5\% to $10 \%$ of the population, so as to suppress political opposition. Under severe interrogations, with beatings, sleep deprivation, and isolation, almost everyone confessed, thereby providing public justification for the arrests. ${ }^{82}$ The widespread torture interrogation programs under Latin American dictatorships during the "dirty wars" are well known. Between 1987 and 1994, the Israeli General Security Service officially interrogated 23,000 Palestinians. An interview study of 700 of these interrogees found that $94 \%$ had been tortured or severely abused. ${ }^{83}$ In the current U.S. invasion of Iraq, former Pentagon strategist Larry Seaquist reportedly described the army's torture of Iraqi detainees at Abu Ghraib prison, publicly revealed in May 2004, as "all of a piece with a national dragnet for 'bad guys'., 84

The Air Force interrogator gave a feeling for this style of diffuse data collection on terrorists in Turkey a couple of decades ago: "When a nation declares martial law, all the interrogators go into high gear and work until exhausted and then some....[Y]ou can conduct five or six normal-level interviews and suddenly you have a "holding pen" of several thousand people...." The difficulty "from a purely intelligence point of view," as noted by Horne, is that "more often than not the collating services are overwhelmed by a mountain of false information extorted from victims desperate to save themselves further agony.", 86

Dragnet interrogation indeed provides more data, but it does not discriminate between truth and lies. Turning to the related criminological studies, truth and lie detection falls into a conflicted area. Contemporary police interrogation manuals provide time-tested schemas for truth and lie detection by eminent practitioners in the criminal justice system. Manuals discriminate truth tellers from liars through numerous verbal and nonverbal behaviours, often linked to involuntary physiological responses. ${ }^{87}$ Partly contradicting this literature of interrogation expertise, experimental studies have 
found that the short-term success rate of professional lie catchers-police officers, detectives, prison guards, customs officers, and the like-falls mainly in the $45 \%$ to $60 \%$ range, where $50 \%$ is the chance rate. In these experiments, professional lie catchers only differed from nonprofessionals in their high level of confidence! The professionals' unwarranted confidence was traced to lack of feedback in the workplace regarding the accuracy of their judgments and to their false reliance on behavioural signs of deceit, such as gaze aversion. (Their over-confidence accords with the general tendency for poor performers on cognitive tasks to overestimate greatly their performance success. $)^{88}$ In fact, behavioral signs of deceit differ across liars and constitute only a small effect.

Accuracy of lie detection has been raised to the $70 \%$ to $85 \%$ level through arduous technical methods, such as film analysis of micro-facial expressions, content analysis of testimony, polygraphy by independent examiners, etc. Yet even these methods may fail due to individual differences ${ }^{89}$ and can be counteracted by trained subjects. ${ }^{90}$ As a striking example, in a 2002 debriefing by the U.S. Defense Intelligence Agency, an Iraqi defector provided the sole testimony to Iraq's mobile biological warfare research laboratories, one of the principal rationales for the U.S.-led invasion of Iraq. Although the defector had passed a polygraph test, he has since been suspected as an Iraqi double agent trained to deceive polygraphers. ${ }^{91}$ Torture, which exaggerates physiological variability in subjects, may complicate objective lie detection.

Because of the large number of detainees and the weak discrimination between the guilty and the innocent, dragnet interrogation requires much coordination between torture interrogation units and (a) the police, (b) the judiciary, and (c) the larger military institution and government. I examine in turn these facets of an official torture interrogation program.

Coordination of a Torture Interrogation Program with the Police. The U.S. "war on terrorism" has driven into close cooperation previously separated, or even estranged, police, FBI, CIA, and military intelligence agencies. As of October 2002, the 18,000 police agencies, with 800,000 officers, vastly outnumbered the other agencies, for example, the $27,000 \mathrm{FBI}$ agents, $58 \%$ of whom worked abroad. ${ }^{92}$ Because of their numbers, networks, jurisdictions, and the urgency of action, in any torture interrogation program the police will be at the forefront of detention and interrogation of terrorist suspects. Indeed, cross-national studies have found that expertise in torture typically passes from the police to military intelligence services. ${ }^{93}$

What error rate should the program anticipate in committing terrorist suspects to torture interrogation? Modern crime statistics indicate that a half to three-quarters of (non-terrorist) suspects arrested and charged with serious crimes are not convicted, depending on the state of jurisdiction ${ }^{94}$ (ignoring false convictions, false acquittals, and dismissals). The proposed torture interrogation program bypasses traditional judicial safeguards, such as the 5th Amendment right against self-incrimination; the 6th Amendment right to counsel; and the 14th Amendment Due Process approach to voluntariness of confession. Moreover, in tracking terrorist operations it is customary to interrogate individuals just because they are acquainted with a person who has been 
detained, not because they are suspected of crimes. ${ }^{95}$ The secrecy and urgency of terrorist cases certainly cannot improve the rate of accuracy over other serious criminal charges. A torture interrogation program, therefore, can anticipate that at least a half to three-quarters of terrorist suspects may be arrested mistakenly. In rough agreement with this estimate, according to news reports of the May $2004 \mathrm{Abu}$ Ghraid prison abuse scandal, U.S. military officials estimated that "at least 60 percent" $"$ "and "between 70 percent and 90 percent" ${ }^{\prime 97}$ of the prisoners had been arrested by mistake.

The nondescriptness of most terrorists is a special source of error. In search of terrorist profiles, a 1999 government report on The Sociology and Psychology of Terrorism synthesized dozens of cross-cultural empirical studies. ${ }^{98}$ Contrary to stereotypes, the report concluded that terrorists are "practically indistinguishable from normal people" in terms of outward appearance. They do not have "visibly detectable personality traits that would allow authorities to identify a terrorist," and they are not "diagnosably mentally disturbed"- except for an occasional psychopathic top leader. Terrorist organizations tend to weed out the conspicuous and the mentally ill as liabilities.

How will the counterterrorist program uphold a monopoly on the use of torture? Investigators of many other crimes will consider their own pursuits compelling, some at the level of national security. ${ }^{99}$ As indication of this tendency, the October 2002 USA Patriot Act, which suspends important civil liberties in pursuit of terrorists, has been applied broadly to serial murder, corporate fraud, blackmail, child pornography, and other crimes without direct links to terrorism. ${ }^{100}$

Both U.S. and British judiciaries have struggled for decades with the overwhelming ill consequences of coercive interrogation, which include false confessions and false testimony; police deception and manipulation of courts; failure of systems of oversight; and involvement of organized crime. ${ }^{101}$ False confessions have been estimated to occur three to four times more often in homicide cases than other criminal cases, because of tougher interrogations by police and because of plea bargains by defendants to avoid the death penalty. ${ }^{102}$ The 1956 Miranda rights for suspects in the U.S. and the 1986 Police and Criminal Evidence Act in Britain stipulate conditions of fair interrogation ${ }^{103}$ and, in principle, require judges to reject all but demonstrably voluntary confessions. ${ }^{104}$ On the whole, analyses of subsequent police interrogations have found negligible change in percentage of valid confessions. ${ }^{105}$ For reliability, professional police practice leans toward "extrinsic evidence independently secured through skilful investigation" 106 and away from confession evidence with its epistemic, ethical, and practical problems. ${ }^{107}$

A U.S. program of torture interrogation engenders the monumental task of discriminating between terrorist and nonterrorist criminal suspects, in spite of many overlapping criminal activities, and of restricting torture interrogation to key terrorists. Yet police departments are still struggling to transform a history of counterproductive coercive interrogation into a modern professional practice of efficient and accountable interrogation. 
Coordination of a Torture Interrogation Program with the Judiciary. Intelligence agencies around the world strongly resist interference from the judiciary and attorneys, who are often perceived as politically liberal, uninformed, and infiltrated by the opposition. In any case, the judiciary becomes a security risk for sensitive operations. The Argentine General Acdel Vilas, who was active in counterinsurgency operations in the early 1970s, afterwards described how he circumvented judicial procedures. $\mathrm{He}$ sent out plainclothesmen instead of uniformed officers to pick up suspects, then passed only the insignificant suspects into the justice system. The plainclothes approach, however, jeopardized his officers, and he had to cover for their deaths in irregular circumstances. ${ }^{108}$ General Aussaresses wrote of an important terrorist who refused to confess: “...I'm convinced he won't say a word [under torture]. If there were to be a trial and he hasn't confessed, he could actually walk away free.... So let me take care of him before he becomes a fugitive..." Aussaresses himself hung the terrorist, as a weakly staged suicide. ${ }^{109}$ The Israeli Supreme Court found that interrogators from the General Security Service (GSS) routinely gave false testimony about coerced confessions to conceal its methods from terrorists, to secure convictions where evidence was lacking, and simply because false testimony succeeded. GSS interrogators insisted that they only lied in cases of actual guilt, and "[o]ne cannot clean sewers without dirtying oneself." "In the British criminological literature, this is called "noble cause corruption": self-sacrificing agents falsify cases and perjure themselves in court to convict people they believe to be criminals. ${ }^{11}$ Nevertheless, both British and Israeli security services have been shamed by notorious cases of the conviction of innocents after coerced confessions, false testimony by interrogators, and contrived evidence. ${ }^{112}$

Can the judiciary oversee an interrogation program? The U.S. judiciary, with its publicly elected and politically appointed judges, is not designed to hold its own against intelligence agencies, especially in matters of national security. Dershowitz has proposed legalization of torture in ticking-bomb cases by requiring "torture warrants" from judges, by analogy with search warrants. ${ }^{113}$ But the ticking bomb scenario itself does not afford judicial consideration of torture warrants for specific individuals on specific occasions. A former Brazilian police officer explained: "It is necessary to get the information now because from now on to the future it might be too late. And to save time, everything is valid." 114

Within intelligence agencies, concealment of security operations is a professional virtue, not a moral flaw. ${ }^{15}$ A colleague's obituary for Richard Helms, former Director of Central Intelligence, praised him "for standing up to the pressures" of a 1977 U.S. Senate investigation "to betray secrets that could be damaging to the country." Intelligence professionals in the field are usually more skilful in methods of concealment than those dispatched to monitor them. The Air Force interrogator provided an example: ${ }^{117}$

[E]very other year an inspector would stop by and ask what we all would do if ordered to eliminate a foreign national. We would all say, "Report them as per regulations." Then the inspector would leave. Then what we were told to do was 
often in conflict with this idea. In Lebanon we put our pro-U.S. warlord in charge and with the help of Shiites in Iran, [the foreign national] was assassinated.

The utilitarian moral rationale for torture interrogation of terrorists provides no plausible mechanism for coordinating interrogators with the judiciary but would seem to support interrogators' idealistic motivations to present false testimony in court and to thwart oversight. A legal analysis of Israeli torture in the Occupied Territories concluded that in a liberal democracy torture subverts the rule of law and erodes other democratic ideals supported by the rule of law. ${ }^{118}$

Accommodation of a Torture Interrogation Program within the Military and the Government. Rood reasoned from historical examples that, like the Nazi Deaths Head $\mathrm{SS}$, an elite torture interrogation corps would be isolated from the regular military and intelligence. Its commander would inevitably gain special powers, and his elite corps would have a destabilizing effect on the military and government ${ }^{119}$

Illustrative of destabilization of the military, under the leadership of several generals the Brazilian military gradually eliminated torture between 1975 and 1986 to save itself as an institution. With counterterrorist agencies working outside the law, torturers graded into "smugglers, blackmailers, and extortionists, and no one dare[d] to stop them." Torturers scorned and controverted the chain of command, creating two factions and destabilizing the army. ${ }^{120}$ Illustrative of the destabilization of government, near the end of his life President Franklin Roosevelt commissioned a study that advised disbanding the Office of Strategic Services - the World War II covert operations agency whose only rule was to win ${ }^{121}$ — so as to preclude a "post-war Gestapo". 122 Illustrative of the risk of excessive of powers, in 1962 the U.S. Joint Chiefs of Staff considered framing Cuba for a terrorist campaign on America, as a pretext for invading Cuba. ${ }^{123}$

Military wisdom cautions that the long-term potential of a weapon or tactic is more important than its initial purpose. ${ }^{124}$ Regardless of the initial purpose, resources invite new uses and are adopted by new users, as demonstrated by the spread of atomic weapons. To this point, a recent issue of the Military Intelligence Professional Bulletin expressed concern that "The Patriot Act" approved by Congress on October 26, 2001, would 'expand the definition of 'terrorist' to include non-violent protesters at an antiwar rally." "125 Indeed, such a strategic expansion of the target group occurred under the Alien Enemy Act in World War II. The incarceration of 7,000 German Americans partly resulted from a policy of arbitrary arrest to intimidate the German American community as a whole. The deportation of 4,000 Latin Americans of German ancestry to U.S. internment camps partly resulted from their utility for prisoner exchange with the Germans and from local greed for their properties. ${ }^{126}$ The FBI and Bureau of Justice labelled people of German ancestry "potentially dangerous" on the basis of unverified accusations by neighbours, friends, business competitors, and disgruntled employees. ${ }^{127}$ Under the proposed U.S. torture interrogation program, such detainees would be in line for torture as well as incarceration.

Utilitarian proponents of torture interrogation posit an isolated program that filters out dangerous terrorists, with minimal side effects. But this program, with its special powers, high secrecy, and deception, cannot be smoothly embedded in a democratic 
political system equilibrated by competing institutions. ${ }^{128}$ In a national security environment, police, judicial, military, and government authorities are largely unable to check the excesses of torture interrogation units. A U.S. Army chaplain averred, "We just cannot go there. It would change our national identity." 129

\section{ROGUE MODELS OF TRUTH TELLING UNDER TORTURE}

The grave, unintended consequences of overt state-sponsored programs of torture interrogation have made covert programs attractive. In the rogue models, torture is not necessarily the causal factor in extracting the truth from captives but may be emotionally, culturally, or historically inseparable from customary tactics. Or torture may be one tactic among many in a hit-or-miss approach fostered by lack of accountability for errors.

One much discussed rogue option is outsourcing to foreign intelligence services. In the Korean War, for instance, U.S. troops commonly turned over North Korean spies to South Korean intelligence for torture interrogation. ${ }^{130}$ The Association of Former [U.S.] Intelligence Officers acknowledged outsourcing in its October 21, 2001, newsletter: ${ }^{131}$

[S]ince Sept. 11, the CIA has arranged for 230 suspects in 40 countries around the globe to be jailed and questioned. One notable aspect of putting possible terrorists in the hands of foreign security services is that [those] states ... use interrogation methods that include torture and threats to family members.

In November 2003, an Amnesty International Press Release reported the U.S. deportation of Syrian-born, Canadian citizen Maher Arar to the Syrian military as an example of outsourcing torture interrogation. ${ }^{132}$ The loss of control over information and the creation of political debts discourages outsourcing though.

A second rogue option is the discreet use of illegal, government-sponsored torture. For example, in a scenario used by the Israeli Secret Services, Palestinian detainees were tortured for information in their prison cells by Israeli collaborators disguised as fellow detainees. ${ }^{133}$ Secrecy can be maintained through plausible deniability, isolation of torture sites, expendability of torturers, and initial recruitment of torturers trained elsewhere (e.g., abroad, in prisons, by abusive families) and by expendability of torturers. In his study of "The Dark Art of Interrogation" for the October 2003 Atlantic Monthly, investigative reporter Mark Bowden concluded that interrogators should be legally forbidden to torture detainees, but with the quiet understanding that torture interrogators who extract vital information from terrorists will not be prosecuted. ${ }^{134}$ Bowden though made no provisions for exposed torturers who fail to extract useful information, who torture ignorant or innocent suspects by accident, or whose services are manipulated for political purposes; nor did he propose solutions for the inevitable medical professionals and other contributors to illegal torture sessions.

A U.S. Army combat veteran, Kenneth Kendall, combining his witness of torture interrogations by South Koreans with his "guinea pig" experience at the Nevada Test Site reflected on the means of concealment of such torture: ${ }^{135}$ 
Once you've got what information you need, then - it's hard to do-but go ahead and finish killing them and erase them from existence, and then that would cover you from the dilemma of having to admit that you did something like this. If there's only a small number of people involved that could ever get out and say anything, then you can insist that they didn't know what they were talking about.- "This guy sung his head off. We didn't have to do nothing with his wife and child. We don't know where they're at." This is probably what I would advise, how this went and all. Primarily based on my past experience.

Hundreds of self-identified survivors of alleged government-sponsored experiments - in such self-help organizations as the Advocacy Committee for Human Experiment Survivors-Mind Control (ACHES-MC), Stop Mind Control and Ritual Abuse Today (SMART), SurvivorShip, and Citizens against Human Rights Abuses (CAHRA) - would endorse Kendall's view. ${ }^{136}$

The "information services" of domestic criminal enterprises offer a third rogue option. It is a truism of criminology that organized crime supplies the goods and services for which there is strong demand but no legal avenue for supply. Narcotics, "snuff" (i.e., actual murder) films, child pornography, transplant organs, artefacts from archaeological sites, art treasures, and illegal weapons are familiar examples. In World War II, the U.S. Navy turned to the Sicilian-American Mafia for information about German U-boats off the Atlantic seaboard and the invasion of Sicily. ${ }^{137}$ Organized crime also runs "information services" that include torture interrogation. ${ }^{138}$

From an organizational perspective, these three rogue options are attractive because the services can be utilized according to need, with an elasticity difficult for state bureaucracies. Moreover, training, monitoring, silencing, and disposal of participants can be managed with relatively little involvement or corruption of U.S. government institutions because few official liaisons need be involved. The practical liability is the difficulty in breaking off or limiting relationships with rogue collaborators, on account of sensitive information held in "dirty hands." In effect, terrorist information is purchased through long-term tolerance of political and criminal wrongdoing, under the euphemism, "protection of sources and methods."

Utilitarians may argue that society is better off legalizing and regulating torture because it is impossible to prevent it. ${ }^{139}$ But an official U.S. program of torture interrogation could not eradicate rogue services. The services are independently maintained by other political and criminal interests, and they would still serve to circumvent ethical and procedural constraints on the official program.

\section{SUMMARY AND ASSESSMENT OF A U.S. TORTURE INTERROGATION PROGRAM}

Returning now to the proposed official program of torture interrogation, here is a rough schema of notable inputs and outputs, according to causal model.

Table 2. Notable Program Inputs and Outputs According to Causal Model of Torture Interrogation

\section{The animal instinct model of truth telling, for the ticking-bomb scenario}




\section{J. M. Arrigo}

(The torturer creates a situation so threatening that the subject's animal instinct for survival overrides his human will or reason and he yields the information requested to preserve his life or relieve pain.)

Intended inputs

- Terrorists with plans of mass destruction

- Basic torture techniques

- Ordinary police and military interrogators

Unintended inputs

- Medical personnel at interrogation sites

Intended outputs

- Foreknowledge of terrorist plans of mass destruction

- Harmless terrorist prisoners

- Unharmed interrogators

Unintended outputs

- Schisms and resistance in the medical community

- Death of suspects under torture or impairment of mental faculties

\section{The cognitive failure model of truth telling, for fanatics, martyrs, and heroes}

(The torturer disorients the subject to the point where he is cognitively unable to maintain a position of self-interest and becomes suggestible or compliant.)

Additional intended inputs

- Terrorists resistant to coercion

- State-of-the-art torture interrogation techniques

- Teams of highly trained torturers

Additional unintended inputs

- Biomedical research on torture techniques

- Establishment of torture interrogation unit(s)
Additional intended outputs

- General knowledge of terrorist operations and terrorist psychology

Additional unintended outputs

- Inseparable mixtures of truth and lies regarding terrorist plans

- Illegal, opportunistic bio-medical research on human subjects.

- Spread of technologies of torture, resistance, and detection to foreign governments and terrorist organizations

- Devastation of torture personnel

- Terrorist infiltration of program

3. The data processing model of knowledge acquisition, for dragnet interrogations (High-powered data analysis produces reliable information from vast quantities of weak data generated by indiscriminate torture interrogation of numerous detainees.)

Additional intended inputs

- Terrorist suspects and possible associates

- Bureaucratic apparatus for comprehensive data management and analysis.

- Police assistance

- Judicial oversight.

Additional unintended inputs

- Persons uninvolved in terrorist activities

- Innocent and ignorant subjects
Additional intended outputs

- Understanding of social process of terrorist organizations, with actionable knowledge

Additional unintended outputs

- Accidental torture of uninvolved persons

- Opportunistic torture interrogation of other

classes of criminal suspects and political

dissidents

- Institutional degradation of police

- Institutional degradation of judiciary

- Institutional degradation of the military and government

Policy studies demonstrate that program success in balancing intended inputs and outputs against unintended inputs and outputs depends on formal access by outsiders and on provisions for independent evaluation studies. ${ }^{140} \mathrm{~A}$ criminological study of 
police interrogation methods over a 50-year period concluded that "all police interrogations should be witnessed by observers who are both independent of police and empowered to act on behalf of suspects by preventing escalation of inherently coercive pressures." ${ }^{141}$ In the case of a torture interrogation program, such a safeguard is impossible for security reasons.

In my view, it remains for utilitarian advocates of a practical U.S. interrogation program to plan for social repair after the inevitable breakdowns of institutions and community. In country after country where national security threats drove torture of domestic enemies - South Africa, Chile, Argentina, Uruguay, El Salvador, Guatemala, Ireland ...-human rights researchers have shown the inadequacies of various attempts at social repair, including criminal trials, truth commissions, reparations to victims, and community mourning rituals. One intractable element is the great majority of bystanders. Bystanders' passivity facilitated the social breakdown but bystanders cannot be held accountable for the repair. ${ }^{142}$ Another intractable element is the disparity between repair policies effective at the state level and policies effective at the individual level. A victim group accused the South African Truth and Reconciliation Commission of "reconciliation showbiz", for substituting disclosure of wrongdoing for prosecution of wrongdoers. ${ }^{143}$ The National Association of Radiation Survivors accused the 1993 U.S. President's Advisory Committee on Human Radiation Experiments of "giving the government what the government paid them for"-a coverup job. ${ }^{144}$ When grievances, such as torture of innocents, cannot be excused or remedied by the state, scapegoating, cover-up, discrediting of victims, and token reparations easily emerge as fraudulent social repair tactics.

The counterargument, of course, is that in a society destroyed by terrorism there will be nothing to repair. That is why the actual causal mechanism of torture interrogation in curtailing terrorism must be elucidated by utilitarian advocates rather than presumed.

A criminological analysis of 500 British court cases found that police interrogation of defendants contributed little to discovery and conviction. Rather, the study concluded that interrogation fulfilled certain psychological and administrative needs and that "police perceptions of reality dominate the criminal process." ${ }^{\text {"145 }}$ Unless the question of long-term efficacy of torture interrogation of terrorists is settled, advocates are liable to the charges of making excuses for inflicting suffering on others ${ }^{146}$ and imposing torture for social control. ${ }^{147}$ The torture-truth connection in the ticking bomb scenario may be one of those false beliefs of "folk psychology" that persist in spite of contrary evidence, such as the false belief that corporal punishment of children induces good conduct and respect for authority. ${ }^{148}$

The historical record suggests that initial gains from torture interrogation are later lost through mobilization of moral opposition, both domestically and internationally, and through demoralization or corruption of the torturers and their constituencies. In a final assessment of the efficacy of the French torture campaign in Algiers, Horne wrote: "the stunning, cumulative impact it had was materially to help persuade public opinion years later that France had to wash her hands of the sale guerre." Winning the Battle of Algiers meant losing the war. ${ }^{149}$ 


\section{CONCLUSION}

Alan Dershowitz closed his essay on "Torture of Terrorists" with this challenge: ${ }^{150}$

Had law enforcement officials arrested terrorists boarding one of the airplanes [of the September 11 disaster] and learned that other planes, then airborne, were headed toward unknown occupied buildings, there would have been an understandable incentive to torture those terrorists to learn the identity of the buildings and evacuate them.

I would like to close my essay with a reply.

Individual law enforcement officials, of course, may "feel an incentive" to torture terrorists. But if it is state policy to torture terrorists, then the policy should be rational and the torture interrogation proceed with a fair chance of success.

Terrorists selected for such a role can probably stand up to commonplace tortures from untrained and unequipped staff for a long time-like most American POWs in North Vietnam. The use of sophisticated torture techniques by a trained staff entails the problematic institutional arrangements I have laid out: physician assistance; cutting edge, secret biomedical research for torture techniques unknown to the terrorist organization and tailored to the individual captive for swift effect; well trained torturers, quickly accessible at major locations; pre-arranged permission from the courts because of the urgency; rejection of independent monitoring due to security issues; and so on. These institutional arrangements will have to be in place, with all their unintended and accumulating consequences, however rarely terrorist suspects are tortured. Then the terrorists themselves must be detected while letting pass without torture a thousand other criminal suspects or dissidents, that is, avoiding a dragnet interrogation policy.

The moral error in reasoning from the ticking bomb scenario arises from weighing the harm to the prospective innocent victims against the harm to the guilty terrorist. Instead - even presuming the doubtful, long-term success of torture interrogation - the harm to innocent victims of the terrorist should be weighed against the breakdown of key social institutions and state-sponsored torture of many innocents. Stated most starkly, the damaging social consequences of a program of torture interrogation evolve from institutional dynamics that are independent of the original moral rationale.

Acknowledgments: Many colleagues have made crucial contributions to this cross-disciplinary essay. For consultations and interviews on military intelligence, I thank William Casebeer, Paul Copher, Ernest Garcia, Kenneth Kendall, Tony Pfaff, Lawrence Rockwood, and Harold William Rood; for legal consultation, Barak Cohen; and for philosophical consultation, Charles Young. 
For responses to my queries on the intelligence list-serves of Cass Publishers' Intelforum (http://www.intelforum.org/) and the Association of Former Intelligence Officers (http://www.afio.com), I thank: Robin Bhatty, Drake Currie, Mike Dravis (moderator), Harlan Girard, Stephen Godjas, Brendan Howley, Howell McConnell, Bill Oliver, Pauletta Otis, Lewis Regenstein, Richard Thieme, Allen Thomson, Douglas Vaughn, Nigel West, and Mike Yared.

For responses to my query on the list-serve Ask-a-Philosopher, sponsored by Sheffield University for the International Society of Philosophers (http://go.to.ask-a-philosopher, I thank: Sean Allen-Hermanson, Steven Bullock, Anthony Flood, Hubertus Fremery, Geoffrey Klempner (moderator), Derel Dov Lerner, Harry Lesser, Gerald Marsh, Matthew del Nevo, Michael Neumann, and Duncan Richter.

For critique of the manuscript, I thank Barak Cohen, John Crigler, Stuart Oskamp, and two anonymous journal referees.

An earlier version of this paper was presented at the Joint Services Conference on Professional Ethics, January 2003, Springfield, VA.

\section{REFERENCES}

1. Solomon, A. (2001, December 4) The case against torture [Electronic version.]. The Village Voice.

2. McLaughlin, A. (2001, November 14) How far Americans would go to fight terror. The Christian Science Monitor: 1 \& 4.

3. Based on 2417 votes. - Crimeweek Daily. http://crime.miningco.com/gi/pages/poll.htm?poll_id=2149603124\&linkbak [Accessed February 11, 2004].

4. Dershowitz, A.M. (2002, January 22) Want to torture? Get a warrant. San Francisco Chronicle: A-19.

5. Hersh, S.M. (2004, May 10). Annals of national security: torture at Abu Ghraib [Electronic version]. The New Yorker.

6. Roeloffsma, D.K. (2004, May 3). The editor: torture, an ugly, perennial question. Association of Former Intelligence Officers Weekly Intelligence Notes, WIN \#41-04. [Available online: http://www.afio.com/sections/wins/index_2004.html. Accessed May 6, 2004].

7. Rawls, J. (1955) Two concepts of rules. The Philosophical Review, 44 (1): 3-32.

8. Trinquier, R. (1964) Modern warfare: a French view of counterinsurgency. Praeger, New York. pp. $21 \& 23$.

9. Salmon, M.H. (2003) Causal explanations of behaviour. Philosophy of Science 70 (4): 720-738. pp. $720 \& 721$.

10. Mazmanian, D. \& Sabatier, P. (1989) Implementation and public policy (2nd ed.) University Press of America, Lanham, MD: Ch. 2.

11. Hoffman, B. (2002, January) A nasty business. The Atlantic Monthly: 49-52. p. 52.

12. duBois, P. (1991) Torture and truth. Routledge, London. pp. 50, 51, \& 66.

13. Hinkle, L.E. (1961) The physiological state of the interrogation subject as it affects brain function. In A.D. Biderman \& H. Zimmer (Eds.) The manipulation of human behavior. Wiley, New York: 19-49. p. 19.

14. Afshari, R. (2001) Tortured confessions [review of Tortured confessions: prisons and public recantations in modern Iran, by E. Abrahamaian, 1999]. Human Rights Quarterly, 23 (1): 290297. p. 294.

15. An overview and bibliography appear in: Vesti, P., \& Somnier, F. E. (1994) Doctor involvement in torture: a historical perspective. Torture 4 (3): 82-89.

16. Rasmussen, O. V. (1992) Medical aspects of torture [Special issue]. Danish Medical Bulletin 37 (1): $1-88$.

Smidt-Nielsen, K. (1998) The participation of health personnel in torture. Torture 8 (3): 93. 
Vesti, P.B. (1990) Extreme man-made stress and anti-therapy. Doctors as collaborators in torture [Electronic version, abstract]. Danish Medical Bulletin 37 (5): 466-468.

17. School of the Americas. $(1983,1984,1988)$ Human resource exploitation training manual. United States Army School of the Americas, Fort Benning, GA: Section H-24. [Released in 1997 under the Freedom of Information Act. Available through Psychologists for Social Responsibility, 2607 Connecticut Ave. NW, Washington, DC 20008.]

18. Sobti, J.C., Chaparwal, B.C. Choudhary, P.K., Holst, E. \& Bhatnagar, N.K. (undated, c. 1996) Knowledge, attitude and practice of physicians in India concerning medical aspects of torture. Indian Medical Association, New Delhi.-A random sample of 4000 members was surveyed by mail questionnaire. Statistics were based on $743(18.6 \%)$ respondents.

19. Iacopino, V., Heisler, M., Pishevar, S. \& Kirschner, R. H. (1996) Physician complicity in misrepresentation and omission of evidence of torture in postdetention medical examinations in Turkey [Electronic version, abstract]. The Journal of the American Medical Association 276 (5): 396-402.

20. Dôcker, H. (2002) Turkey continues harassment, arrests, and torture of medical doctors. Torture 10 (2): 53.

21. Livingston, G. (1996, December 22) Serving two masters: the ethical dilemmas that military medical students want to avoid - but can't [Electronic version]. Washington Post. p. C3.

22. Oehmichen, M. (1999) The forensic physician's conception of himself. Documentation and prevention of maltreatment and torture as a special task [Electronic version, abstract]. Forensic Science International 100 (1-2): 77-86.

23. Training Mexican doctors to investigate torture. (2002-2003, Winter) Survivors International Outreach 3.

24. Iacopino, V., Keller, A., \& Oskenberg, D. (2002) Why torture must not be sanctioned by the United States [Op-ed.] [Electronic version]. Western Journal of Medicine 176: 148-149. p. 149.

25. Amendment to WMA [World Medical Association] resolution on human rights. (1996) Torture 6 (1): 30 .

26. E.g., Sciolino, E. (2003, January 22) Iran is said to jail 2 lawyers who reported torture charges [Electronic version]. The New York Times.

27. Silverman, L. (2001) Tortured subjects: pain, truth, and the body in early modern France. University of Chicago Press, Chicago. p. 182.

28. Oskamp, S. \& Schultz, P.W. (1998) Applied social psychology (2nd edn.). Prentice Hall, Englewood Cliffs, NJ. p. 34.

29. Greenberg, J., Solomon, V., Mitchell, P., Rosenblat, A., Kirland, S. \& Lyon, D. (1990) Evidence for terror management theory II: the effects of mortality salience on reactions to those who threaten or bolster the cultural worldview. Journal of Personality and Social Psychology 58 (20): 308-318.

30. Van der Kolk, B.A., van der Hart, O. \& Marmar, C.R. (1996) Dissociation and information processing in posttraumatic stress disorder, in: van der Kolk, B.A., McFarlane, A.C. \& Weisaeth L. eds. Traumatic stress: the effects of overwhelming experience on mind, body, and society. Guilford Press, New York: 303-327. p. 307.

31. U.S. Air Force interrogator (2003, February 18) Personal communication.

32. Hoffman, P. (1977) The history of the German resistance: 1933-1945, trans. R. Barry, MIT Press, Cambridge, MA. p. 519.

33. Stockdale, J.B. (2001) Courage under fire, in: Department of Philosophy and Fine Arts, United States Military Academy eds, Moral dimensions of the military profession (5th edn.): 321-334. p. 328.

33a. Campbell, K.J. (2002) Surviving Vietnam's prisons [review of Honor bound: American prisoners of war in Southeast Asia, 1961-1973, by S. I. Rochester \& F. Kiley]. International Journal of Intelligence and Counterintelligence 15 (2): 313-316. p. 314.

34. Glücklich, A. (2001) Sacred pain: hurting the body for the sake of the soul. Oxford University Press, New York. p. 11. 
35. Qouta, S., Punamaki, R.-L. \& Sarraj, E.E. (1997) Prison experiences and coping styles among Palestinian men. Peace and Conflict: Journal of Peace Psychology 3 (1): 19-36. pp. 24-29.

36. Op cit., Afshari, R. (2001). p. 294.

37. Quiroga, J. (2002, February 27) Personal communication.

38. Gudjonsson, G. (1992) The psychology of interrogations, confessions, and testimony. Wiley, Chichester, UK. pp. 217-218.

39. Op cit., Silverman, L. (2001). pp. 8, 9, \& 66.

40. Segal, J. (1957) Correlates of collaboration and resistance behavior among U.S. Army POWs in Korea, in: Bauer, R.A. \& Schein, E.H. eds. Brainwashing [Special issue]. The Journal of Social Issues, 13 (3): 31-40. pp. 31-32, \& 35. [Italics in the original.] - Of 6658 American POWs, 3323 were repatriated. Most of the others died in captivity early in the war, before the Chinese Communists initiated the "brainwashing" program. p. 31.

41. E.g., Toliver, R.F. (1997) The interrogator: the story of Hans-Joachim Scharff, master interrogator of the Luftwaffe. Schiffer, Atglen, PA.

42. Watanabe, S. \& Yokota, K. (1999) Psychological factors that facilitate confession to denying suspects [Electronic version, abstract]. Reports of the National Research Institute of Police Science 40 (1): 37-47.

43. "These captured personnel are very valuable assets to our job in the [Middle East]. We depend on them to keep us up to date, so killing them off was not a good thing....That is why we tried as hard as we could to get the person on our side, to try various methods to convince them we might be able to help [them] if they would come clean."-U.S. Air Force interrogator (2003, February 17) Personal communication.

44. "There were times when I would actually go inside and sleep inside of the cell where they were being held, and sit there with them, and I could pump more information than anybody could pump under force or pain.... What you do is first you work on their confidence, gaining their confidence. You make them believe that you're in the same boat that they are. That you yourself have been a victim of the world. And tell them how dissatisfied you are with the system. It's very easy to do that because you're actually dissatisfied with the system...."-Garcia, E. (1997). On torture interrogation of Nazis and terrorists. Interview conducted by J.M. Arrigo, Albuquerque, NM. Oral History Series on Ethics of Intelligence and Weapons Development. Regional Oral History Office, University of California, Berkeley, CA.

45 . Associated Press. (2003, December 1). Saudi interrogators use new technique [Electronic version]. Washington Post.

46. Maio, G. (2001) History of medical involvement in torture - then and now [Electronic version]. The Lancet, 357 (9268): 1609-1611.

47. Marks, J. (1979) The search for the "Manchurian Candidate"-the CIA and mind control. Times Books, New York. pp. 127-130.

48. U.S. Senate, Select Committee on Intelligence and Subcommittee on Health and Scientific Research of the Committee on Human Resources. (1977) Project MKULTRA: the CIA's program of research in behavioral modification. U.S. Government Printing Office, Washington, DC. pp. 7, 12-13, 123 \& 148-149.

49 . Weinstein, H.M. (1990) Psychiatry and the CIA: victims of mind control. American Psychiatric Press, Washington, DC Pp. 180-181.-The District Court case was: Orlikow v. U.S., 682 F.Supp. 77 (D.D.C. 1988). The Supreme Court case was: CIA v. Sims, 471 U.S. 159 (1985).

50. U.S. Defense Advanced Research Projects Agency (2002, January 7) Weekly Intelligence Notes, 94-02 dtd 28 January 02. http://safe.sysplan.com/scihelpamerica/ad.html.

51. Arrigo, J.M. (1999) Sins and salvations in clandestine scientific research: a social psychological and epistemological inquiry. Unpublished doctoral dissertation, Claremont Graduate University. p. 357.

52. Executive summary: Farwell Brain Fingerprinting. http://www.brainwavescience.com. Accessed December 23, 2002.

53. U.S. Air Force interrogator. (2002, December 23, \& 2003, February 17) Personal communications. 
54. Op cit., Qouta, S., Punamaki, R-L., \& Sarraj, E.E. (1997). p. 26.

55. Zeeberg, N. (1998). Torture - a public health puzzle in Europe. Torture 8 (4a) (Suppl. 1): 2144.

56. Heinz, W.S. (1993) The military, torture and human rights: experiences from Argentina, Brazil, Chile and Uruguay, in: Crelinsten, F.D. \& Schmid, A.P., eds. The politics of pain torturers and their masters: 73-108. Center for the Study of Social Conflicts, Leiden, The Netherlands. P. 80.

57. Amnesty International. (2000) Stopping the torture trade. Amnesty International, New York. p. 34.

58. For example, MKULTRA psychiatrist Ewen Cameron's infamous "psychic driving" experiments.-Weinstein, Harvey M. (1990) Psychiatry and the CIA: victims of mind control. American Psychiatric Press, Washington, DC.

59. Kameda, T., Takezawa, M. \& Hastie, R. (2003) The logic of social sharing: an evolutionary game analysis of adaptive norm development. Personality and Social Psychology Review 7 (1): 2-19. p. 6.

60. Op cit., U.S. Senate, Select Committee on Intelligence and Subcommittee on Health and Scientific Research of the Committee on Human Resources. (1977).

61. Advisory Committee on Human Radiation Experiments. (1995, October) Final report: Advisory Committee on Human Radiation Experiments. U.S. Government Printing Office, Washington, DC.

62. Rood, H.W. (2001 \& 1997) Moral development of an intelligence officer in the clash of civilizations - On torture interrogation of terrorists. Interview conducted by J.M. Arrigo, Claremont, CA. Oral History Series on Ethics of Intelligence and Weapons Development. Regional Oral History Office, University of California, Berkeley, CA.

63. Drogin, B. \& Meyer, J. (2002, April 2) Detainee is bin Laden aide; "He knows where people are." Los AngelesTimes: A1 \& A6. p. A6.

64. Haritos-Fatouros, M. (1993) The official torturer: a learning model for obedience to the authority of violence, in: op. cit., Crelinsten, F.D. \& Schmid, A.P. eds.: 141-160.

65. Op cit., Heinz, W.S. (1993).

66. Allodi, F. (1993) Somoza's National Guard: a study of human rights abuses, psychological health and moral development, in: op. cit., Crelinsten, F.D. \& Schmid, A.P. eds: 125-140.

67. Cohen, S. \& Golan, D. (1991) The interrogation of Palestinians during the Intifada; illtreatment, "moderate physical pressure" or torture? Israeli Information Center for Human Rights in the Occupied Territories, Jerusalem.

68. Crelinsten, R.D. (1993). In their own words: the world of the torturer, in: op cit., Crelinsten, F.D. \& Schmid, A.P. eds: $39-72$. p. 71.

69. Horne, A. (1977) A savage war of peace: Algeria 1954-1962. Macmillan, London. P. 206.- Horne referred to "numerous cases like that of the European police inspector found guilty of torturing his own wife and children, which he explained as resulting from what he had been required to do to Algerian suspects..."

70. Op cit., Heinz, Wolfgang S. (1993) p. 98.

71. McNair, R.M. (2002) Perpetration-induced traumatic stress: the psychological consequences of killing. Praeger, Westport, CT.

72. U.S. Air Force interrogator (2002, December 16) Personal communication.

73. Op cit., Rood, H.W. (1997).

74. Carroll, T.P. (2001) The case against intelligence openness. International Journal of Intelligence and Counterintelligence 14 (4): 559-574. p. 570.

75. Clark, R. (2000) Informers and corruption, in: Billingsley, R., Nemitz, T. \& Bean, P. eds. Informers: policing, policy, practice. Willan, Portland, OR: 38-49. p. 40.

76. Powers, T. (2002, October 10) Secrets of September 11. The New York Review of Books: 47-52. p. 48.

77. Allen, T.B. \& Polmar, N. (1995) Code-name downfall: the secret plan to invade Japan and why Truman dropped the bomb. Simon \& Schuster, New York. 
78. McGee, J. (2001, November 28) Ex-FBI officials criticize tactics on terrorism: detention of suspects not effective, they say [Electronic version]. Washington Post: A01.

79. Aussaresses, P. (2002) The Battle of the Casbah: Terrorism and Counter-Terrorism in Algeria 1955-57. Enigma, New York.

80. Op cit., Horne, A. (1977).

81. Berkowitz, B. (2003, December 19). Learning to break the rules [op-ed] [electronic version]. The New York Times.

82. Op cit., Gudjonsson, G. (1992).

83. Biletzi, A. (2001) The judicial rhetoric of morality: Israel's High Court of Justice on the legality of torture [Electronic version]. Unpublished paper. Occasional Papers of the School of Social Science, No. 9. Tel Aviv University, Tel Aviv Israel. p. 8.-Prime Minister Itzhak Rabin himself admitted that 8,000 prisoners had been subjected to violent shaking.

84. Seaquist, L. (2004, May 5). US military's bad-guy dragnet-a terrible way to win a war. The Christian Science Monitor, p. 9.

85. U.S. Air Force interrogator (2003, January 7 \& February 17) Personal communication.

86 Op cit., Horne, A. (1977) pp. 204-205.

87. E.g., Gordon, N. J. \& Fleisher, W.L. (2002) Effective interviewing and interrogation techniques. Academic Press, San Diego, CA. pp. 19-20.

Zulawski, D.E. \& Wicklander, D.E. (2002) Practical aspects of interview and interrogation (2nd edn.) Boca Raton, FL: CRC.-Photo captions: "Untruthful individuals might posture themselves in a slumping position, extending their legs toward the interviewer" (p. 130); "Truthful individuals generally hold their heads upright" (p. 143).

88. Dunning, D., Johnson, K., Erlinger, J. \& Druger, J. (2003) Why people fail to recognize their own incompetence. Current Directions in Psychological Science 12 (3): 83-87.

89. The U.S. Air Force interrogator gave the example of moral indignation causing a false positive response when the polygrapher accused the subject of a particularly offensive crime.- (2003, February 17) Personal communication.

90. Vrij, A. (2000) Detecting lies and deceit: the psychology of lying and the implications for professional practice. Chichester, UK: Wiley. Pp. 74-76, 96, 159.-Among professional liecatchers, Secret Service members do a little better, and there are rare individuals with high accuracy in lie detection.

"[S]ome professional polygraph examiners claim an accuracy rate of $97 \%$ or above, whereas the scientific evidence indicates a more modest accuracy of about 85\%...."-Op cit., Gudjonsson, G. (1992) p. 185.

91. Landay, J.S. (2004, February 5) Intelligence officials warned that Iraq WMD information was iffy [i.e., uncertain]. Knight Ridder Washington Bureau.

http://www.realcities.com/mld/krwashington/news/columnists/jonathan_s_landay/7886210.htm. [Accessed February 14, 2004].

92. Bowers, F. (2002, October 8) The intelligence divide: can it be bridged? The Christian Science Monitor: 2-3.- Statistics quoted from FBI Director R. Mueller.

93. Op cit., Heinz, W.S. (1993). p. 81.

94. Huff, C. R., Rattner, A. \& Sagarin, E. (1986) Guilty until proved innocent: wrongful conviction and public policy. Crime \& Delinquency 32(4): 518-544. p. 523.

95. Op cit., Crelinsten, R.D. (1993). p. 61.

96. Schmitt, E. (2004, May 15) Top commander bars coercive tactics in interrogation of Iraqis [Electronic version]. New York Times.

97. Ciezadlo, A. (2004, May 17) Iraqis, desperately seeking detainees, meet frustration. The Christian Science Monitor, pp. 1 \& 10.

98. Hudson, R.A. (1999) The sociology and psychology of terrorism: who becomes a terrorist and why? Federal Research Division, Library of Congress. http://www.loc.gov/rr/frd/SociologyPsychology\%20of\%20Terrorism.htm. pp. 56-58. Accessed January 27, 2003.

99. E.g., "[I]f due process is systematically denied to accused al-Qaeda members, one likely consequence is that other categories of accused persons - drug dealers, mass murderers, child 
molesters, etc. - will be labelled as similarly undeserving."-Neier, A. (2002, February 14) The military tribunals on trial. The New York Review of Books: 11-15. p. 14.

100. Lichtblau, E. (2003, September 28). U.S. uses terror law to pursue crimes from drugs to swindling [electronic version]. New York Times.

101. Gordon, N.J., \& Fleisher, W.L. (2002) Effective interviewing and interrogation techniques, Academic Press, San Diego, CA. p. 29.

102. Gross, S.R. (1998, Autumn). Lost lives: miscarriages of justice in capital cases [Electronic version]. 61 Law \& Contemporary Problems.

103. Op cit., Gudjonsson, G. (1992).

104. Skolnick, Jerome H. \& Fyfe, James J. (1993) Above the law: police and the excessive use of force. Free Press, New York.

105. E.g., Pearse, J. \& Gudjonnson, G.H. (1996) Police interviewing techniques at two South London police stations [Electronic version, abstract]. Psychology, Crime \& Law 3 (1): 63-74.

106. Fricks, R.L. (1997) Criminal confessions: scriptural basis and criminal jurisprudence reconciled [Electronic version, abstract]. Unpublished master's thesis, School of Law, Robertson School of Government, Regent University, Virginia Beach, Virginia. p. 14.

107. Kassin, S.M. (1997) The psychology of confession evidence [Electronic version, abstract]. American Psychologist 52 (3): 221-233.

108. Op cit., Heinz, W.S. (1993) p. 87.

109. Op cit., Aussaresses, P. (2002).

110. Gur-Arye, M. (1989) Excerpts of the Report. Symposium on the report of the Commission of Inquiry into the Methods of Investigation of the General Security Service Regarding Hostile Terrorist Activity [Special issue]. Israel Law Review 23 (2 \& 3): 146-188. pp. 161-162.

111. Op cit., Gudjonsson, G. (1992). pp. 269 \& 272.

112. For a British example, see the "Birmingham Six," in: op cit., Gudjonsson, G. (1992) pp. 269 \& 272.

For an Israeli example, see the "Nafsu case" in: op cit., Gur-Arye, M. (1989) Introduction. pp. 149-152.

113. Op cit., Dershowitz, A.M. (2002, January 22). p. A-19.

114. Op cit., Heinz, W.S. (1993). p. 95.

115. Chapman, R.D. (2002) The new intelligence agenda [review of Bombs, bugs, drugs, and thugs: Intelligence and America's quest for security, by L. K. Johnson.]. International Journal of Intelligence and Counterintelligence 15 (1): 133-143. p. 143.

116. Jonkers, Roy. (2002, November 18) In memoriam. Association of Former Intelligence Officers Weekly Intelligence Notes 44-02. http://www.afio.com/sections/wins/index_2002.html.

117. U.S. Air Force interrogator (2003, January 6) Personal communication.

118. Cohen, B. (2001) Democracy and the mis-rule of law: the failure of the Israeli legal system to prevent the torture of Palestinians [Electronic version]. 12 Indiana International and Comparative Law Review 75.

119. Op cit., Rood, H.W. (1997).

120. Wechsler, L. (1991) A miracle, a universe: settling accounts with torturers. Penguin, New York. p. 66.

121. Op cit., Moon, T. (1991) p. 321.

122. Schwab, S.I. (2002) Forging a durable alliance [review of the book Roosevelt and Churchill: men of secrets, by D. Stafford, 2000]. International Journal of Intelligence and Counterintelligence 15 (1): 144-149.

123. Anderson, R. (2002) [Review of the book Body of secrets: Anatomy of the ultra-secret National Security Agency, from the Cold War though the dawn of a new century, by J. Bamford]. Intelligence and National Security 17 (1): 16-18. p. 17.

124. Kane, T.M. (2002, March) Strategic analysis: to hear the thunder. Military Intelligence Professional Bulletin: 4-7. p. 6.

125. Ley, M.P. (2002, March) Editors note. Military Intelligence Professional Bulletin: 36. 
126. Fox, S. (2000) America's invisible Gulag: a biography of German American internment and exclusion in World War II. Peter Lang, New York. pp. xv.\& xviii.

127. Crockett, R.F. (2002) America's invisible gulag. [Review of the book America's invisible gulag, by S. Fox, 2000]. The Oral History Review, 29 (2): 192-195. p. 192.

128. For an exposition of morality as a negative feedback control system, see: Chambers, J. (2001) A cybernetic theory of morality and moral autonomy. Science and Engineering Ethics 7: 177-192.

129. Moore, R.G. (2003, February 4) Personal communication from an ethics instructor at the U.S. Army Logistics Management College, Fort Lee, VA.

130. Kendall, K. (1996 \& 1997) My life, not the lives of my children, for my country! — On torture interrogation in the Korean War. Interview conducted by J.M. Arrigo, Portage, IN. Oral History Series on Ethics of Intelligence and Weapons Development. Regional Oral History Office, University of California, Berkeley, CA.

131. Jonkers, R. (2001, October 15) Disruption as an anti-terrorist weapon. Association of Former Intelligence Officers Weekly Intelligence Notes 41-01: http://www.afio.com/sections/wins/2001/2001-41.html]

132. USA: Deporting for torture? (2003, November 14). Amnesty International Press Release. http://web.amnesty.org/library/Index/ENGAMR511392003?open\&of=ENG-USA. Accessed February 14, 2004.

133. Gordon, N. (2002). Outsourcing violations: the Israeli case. Journal of Human Rights 1 (3): 321-337. p. 328.

134. Bowden, M. (2003, October). The dark art of interrogation. The Atlantic Monthly. pp. 51-58, 60, $62,64-65,68-70,72-74, \&$ 76. p. 76

135. Op cit.: Kendall, K. (1996 \& 1997).

136. Judging from newsletters and personal communications with members. ACHES-MC, 363 Pearl St., \#2, Thunder Bay, Ontario, P7B1E9; http://www.aches-mc.org. SMART, P.O. Box 1295, Easthampton, MA 01027; http://www.members.aol.com/SMARTNEWS. SurvivorShip, 139 Mission St., San Francisco, CA 94110; http://www.survivorship.org. CAHRA: http://www.dcn.davis.ca.us/ welsh/ (primarily concerned with electro-magnetic resonance targeting of civilians).

137. Campbell, Rodney. (1977) The Luciano Project: the secret wartime collaboration of the mafia and the U.S. Navy. New York: McGraw-Hill.-Based on the 1954 files of the New York State Commissioner of Investigations.

138. Anonymous. Personal communications from four participants.

139. Op cit., Dershowitz, A.M. (2002, January 22).

140. Op cit., Mazmanian, D. \& Sabatier, P. (1989). p. 28.

141. Leibowitz, R.B. (1991) The psychology of police confession and the impact of Miranda: a study of interrogation methods over a 50 year period [Electronic version, abstract]. Unpublished dissertation. University of California, Santa Cruz.

142. Fletcher, L.E. \& Weinstein, H. (2002) Violence and social repair: rethinking the contribution of justice to reconciliation. Human Rights Quarterly 24 (3): 573-649. pp. 615 \& 625.

143. Hamber, B. \& Wilson, R. A. (2002) Symbolic closure through memory, reparation and revenge in post-conflict societies. Journal of Human Rights 1 (1): 35-53. p. 47.

144. Task Force tells government...we are still seeking justice! (1996, Winter) National Association of Radiation Survivors. 1 \& 3. [Bulletin available from NARS, P.O. Box 2815, Weaverville, CA 96093-2815].

145. McConville, M. \& Baldwin, J. (1982) The role of interrogation in crime discovery and conviction [Electronic version, abstract]. British Journal of Criminology, 22 (2): 165175.-Although not directed to the same point, another source stated that confession evidence is important in the prosecution of about $20 \%$ of criminal cases.-Op cit., Gudjonsson, G. (1992) p. 324.

146. A cognitive process called "moral disengagement."-Grussendorf, J., McAlister, A., Sandström, P., Udd, L. \& Morrison,T.C. (2002) Resisting moral disengagement in support for war. Peace and Conflict: Journal of Peace Psychology 8 (1): 73-83. p. 73. 
J. M. Arrigo

147. Buhelt, A. (2001) Torture in well-functioning democracies. [Book review of Torture in the Basque Country, Report 2000, by TAT Group Against Torture. (1999).] Torture 11 (3): 92.

148. Kazdin, A.E. \& Benjet, C. (2003) Spanking children: evidence and issues. Current Directions in Psychological Science 12 (3): 99-103.

149. Op cit., Horne, A. (1977) pp. 206-207.

150. Dershowitz, A.M. (2002) Torture of terrorists: is it necessary to do and to lie about it?, in: Dershowitz, A.M., Shouting fire: Civil liberties in a turbulent age: Little, Brown, \& Co., Boston: 470-479. p. 477. 